\title{
Forensic Linguistics: A Study in Criminal Speech Acts
}

\section{Dr. Jihan Hassan Mohammed Ali*}

\begin{abstract}
This paper presents Forensic Linguistics (FL) as a relatively new field if it is compared to phonetics, syntax and other branches of

\section{ARTICLE INFO}

Received 2020-04-18

Accepted 2020-05-11

\section{Keywords}

forensic, cybercrime, language crime, criminology, authorship identification, perjury, threatening, and solicitation. linguistics. It is the interface between linguistics and law. It is an interdisciplinary field as it depends upon other fields like semantics, pragmatics, discourse analysis, critical discourse analysis, stylistics and phonology. The paper also proposes its history, development, importance and applications. Forensic linguistics is related to language crimes namely the crimes that are committed by means of language like bribery, perjury, conspiracy, solicitation, plagiarism and threatening. Finally, the conclusions are introduced, i.e. the cooperation between linguists and lawyers. Forensic linguistics, as a promising field, should be regarded and taught to university students and those who work in legal proceedings due to its high importance. Forensic linguistics has significant contributions to the legal context and field.
\end{abstract}

\footnotetext{
* Lecturer of Al-Alsun University, Beni Suef University, Egypt
} 


\section{Aim of the Study:}

This paper aims to raise awareness of the field of Forensic Linguistics (FL) and its significant applications. The paper also introduces language crimes which are linguistically oriented and dependent on the abuse of language. Language crimes like bribery, perjury, libel, solicitation, threatening and conspiracy are dealt with in this paper. These crimes need a good training in pragmatics. An application has followed, with focus on speech acts. Forensic Linguistics is a relatively new branch of linguistics. It is an interdisplinary field, as it depends in its analysis upon many different fields: (critical) discourse analysis, pragmatics, stylistics, conversation analysis, phonetics, phonology, sociology, syntax, semantics, and law, among others.

\section{Statement of the Problem:}

The field of forensic linguistics is relatively new if it is compared to law or linguistics. It is very important to those who work in courts, or study law in particular, and to laymen in general. Ordinary people, according to Roger Shuy, has to deal with a number of legal documents and processes on a regular basis like, for example: real estate, lease agreement, wills, contacts etc. (Shuy, 1993, p.12).

\section{This paper tries to answer the following questions:}

1. What is forensic linguistics?

2. What is the importance of FL?

3. What are the main applications of Forensic Linguistics?

4. What is the domain of Forensic Linguistics?

5. What do forensic linguists do?

6. What are language crimes? 
BSU International Journal of Humanities and social science

\section{Introduction:}

Law is codified in language. Indeed, without language, there is no law.Roger Shuy is of the opinion that the average person cannot read x-ray in the same way the physicians can do. Simply because the physicians are well-trained to do this. In the same manner, linguists are well trained to see and hear structures that are invisible to laymen (Shuy, 1993, p.xvii).Forensic linguistics has made important contributions to the criminal justice system.

The word 'forensic' is defined in Oxford English Dictionary as: an adjective pertaining to, connected with or used in courts of law. From this definition, it can be concluded that Forensic linguistics is an interface between language, crime and law (Khoyi et al., 2014, p.313).

Forensic linguistics, like almost all sciences, has not a specific moment at which it is possible to say it began. Scholars and many others, since the eighteenth century, had problems about the authorship of famous texts, even sacred books and Shakespeare's plays (John Olsson, 2014, p.4).Forensic Linguistics does not have an actual appearance until 1968 with the analysis of Professor Jan Svartivk (The Evans Statement: A Case for Forensic Linguistics) of statements taken by police officers at Notting hill Police Station in 1953. He was the first one to introduce the term forensic. Professor Svartivk is one of the famous linguists who worked a lot in the field of corpus linguistics, which is in turn, a systemic linguistic analysis of bulk and large bodies that are called corpus. This work helped him to work in a scientific way, and to deal with a bulky amount of material.

In 1980s, Australian forensic linguists tried to apply linguistic and sociolinguistic tools to legal cases. In Germany, in 1988, The Federal Criminal Police Office (BKA) held a two-day conference in Forensic Linguistics. The University of Birmingham held in 1992 the first seminar on Forensic Linguistics. Many linguists from Greece, UK, Brazil, and Germany attended. In 1999, the first MA in FL, at Cardiff University was granted. In 

al., 2014, p.222).

Forensic Linguistics (FL) is a branch of applied linguistics which relates and links law to legal processes. In other words, it is the application of linguistics to three main areas, namely written legal texts, spoken legal practices (interactions) and provision of evidence for both civil and criminal investigations and courtroom proceedings (Coulthard, Grant and Kredens, 2011,p.529). In addition, FL involves an application of scientific linguistic knowledge to civil and criminal cases. Forensic linguists are much concerned with the language used by the police in interviews with suspects and witnesses. They are also concerned with the language of lawyers and witnesses in legal proceedings in trials, investigations and sentences (Mohsen, Sajedi and Sajedi, 2014, p.223).

Xuehua $\mathrm{Li}$ argues that FL is a branch of Forensic science like forensic chemistry and forensic psychology. Moreover, forensic linguists have an ethical and professional responsibility, as they provide an objective analysis to legal community with reliable information in order to prevent unfair conviction or acquittal of criminals (2011, p.529).He adds that forensic linguist is a ' a cover term for the language scientist serving as a legal expert' (ibid, p.560).For him, the forensic linguist has two tasks, i.e., to find clues and offer opinions. Clues means linguistic evidence either to the court or jury. The linguist's clues help in forming the formal opinion that is based upon theatrical knowledge and expert's experience.

FL is a science that studies the intersections between language and legal field, which is, in turn linguistically oriented by nature. Persons who are involved in the legal process like lawyers, judges, police officers and members of jury get much benefit from having an awareness of linguistic knowledge (Correa, 2013, p.1).She adds that in dealing with FL, there are some important points that should be taken into consideration: firstly, language is a medium of communication between law enforcement authorities, on one side, and suspects and witnesses, on the other. Secondly, 
it is the medium of interpretation, intelligibility and construction of laws. Thirdly, it is through language that language crimes, linguistic evidence and legal argumentation can be done (ibid, p. 1).

According to Coulthard and Rui Sousa, there are two definitions of FL: narrow and broad. The broad one includes three areas: the written law language, spoken interaction in legal proceedings and language as evidence. The narrow one confines FL to language as evidence. This means that forensic linguists work as expert witness (Coulthard et al., 2011, p.1).More importantly, Coulthard emphasizes the importance of FL as 'the centrality of the use of language in general and the law in particular' (Derin, Evizareza, Deliani and Humuddin, p.1).Moreover, legal language is a distinctive genre of English, as it influences the form, content and interpretation of a legal message (Zadegan, Khoyi and Behnam, 2014, p.312).

Today Forensic Linguistics is a widely recognized science. There are many specialist journals and associations. The International Association of Forensic Linguistics has been established with the aim of bringing together those working on all dimensions of law and language (Grant and Perkins, 2012, p.174). It tries hard to promote and develop research, practice and principles of expert testimony, provision of linguistic evidence and legal interpretation. The ultimate goal is to devise and to establish standards upon which forensic linguist experts can work. The discipline has reached its maturity as an academic field in the 1990s, due to seminars. The need for journals was felt and International Association for Forensic Phonetics was established. Moreover, the key journal in this field is The International Journal of Speech, Language and the Law, previously known as Forensic Linguistics.

Tripartite categories of FL are: study of written legal texts (language), spoken interaction and investigations. 


\section{Written Legal Language:}

Malcolm Coulthard is of opinion that Forensic Linguistics is an interdisciplinary field; it lies between the two fields: law and linguistics (p.3), whereas John Olsson argues that FL is the interface between linguistics (the science of language) and law including law enforcement (John Olsson, 2013, p.3).Language is a medium of communication among law enforcement authorities and suspect/witnesses and a medium of legal argumentations in the courtroom (Shuy, 1993, p.45).

According to Gibbons, law depends upon language to a very large extent; law is an entirely linguistic institution, i.e. laws are codified and interpreted in language. Language enables and constrains laws. Moreover, legal language is seen by many persons as difficult; it can be made simple and easy only by forensic linguists (Gibbons, 2003, p.1).

Shuy states that ordinary people are sometimes obliged to deal with legal documents, and that they find the legal language or the legalese difficult to be understood. Undoubtedly, every field has its jargon. People have the right to understand. Forensic linguists try to facilitate it or make these texts intelligible. They also help in simplifying, interpreting, explaining and formulating codes.

\section{Spoken Legal Language:}

It includes interactions that occur in police investigations, interviews and interactions within the courtroom. Interactions play an important part in legal procedures. So, new researches are conducted upon interaction firstly, among police officers and suspects -before, during, and after arrest; Secondly, upon interaction that occurs with vulnerable people as defendants or as witnesses (Correa, 2013, p.4). 
In the first type of interaction, Paul Grice's cooperative principle and its four maxims (1989) and Austin's theory of speech acts (1975) are very helpful and effective, according to Maite Correa. They help participants who interact to understand the techniques and intricacies of any interaction. One has to follow or obey them to have an effective communication.

\section{Grice's Maxims are as follows:}

Quality: do not say what you believe to be false or that for which you lack adequate evidence.

Quantity: make your contribution neither more nor less than is required.

Relation: be relevant.

Manner: avoid obscurity of expression and ambiguity. Be brief and orderly.

When speakers do not follow the maxims, they flout them. When a speaker flouts one or more of the maxims without deliberate intention he misleads the hearer/listener who tries to reconcile what the speaker says, assuming that the speaker is cooperating with him/her. Flouting the maxims leads the hearer/listener to infer what the speaker means. Grice calls this conversational implicature (Correa, 2013, p.5).

According to Shuy (1997, p.181), there are some techniques that are commonly used during the interrogation and in the courtroom. They are: firstly, yes/no questions which imply more control by the speaker over the hearer than the open-questions do. Secondly, tag questions and questions that presuppose facts that have not yet been established indeed involve more power in controlling evidence (ibid, p.268). The last one is promises and threats. 
Eades explains that the communicative interactive problem is caused by the aboriginal and vulnerable encounter in police investigations, interviews and in courtrooms. These problems and difficulties that they undergo are due to the cultural and linguistic differences among them and the native speakers.

In this respect, forensic linguists can help by proposing ways/methods the police can make use of less coercive language during interactions (Shuy 1997). In this way, the police can avoid ambiguous and improper questions and structures. In case of people and children who suffer from communication disabilities, the forensic linguist should provide a specialized training for lawyers, interviewers and detectives in order to be able to deal with those persons in a fruitful way.

\section{Provision of Evidence:}

Forensic linguists are known as expert witness. Simply they can provide evidence and advice to help police in investigations. They can aid courts and police in authorship identification: a forensic linguist compares an anonymous text to known texts (texts that have identified authors) to decide whether they are written by the same author or not. This analysis is very effective in sms text messages, twitter feeds, and other short texts, especially when someone is missed, supposed to be dead, but his/her mobile phone continues to send messages. Forensic linguists work as consultants to determine whether the suspect messages belong to the same author or not. Professor Malcolm Coulthard is a very good expert in this field. Sociolinguistic profiling is directly related to this application of FL.

Recently, some forensic linguists aid a police Pedophile Unit (adults who are sexually attracted to children) by analyzing and synthesizing texts to help girls to identify those whom they deal with whether they are children or not (Coulthard, 2011, p. 5). 


\section{Sociolinguistic Profiling:}

Forensic linguistics draws upon many different fields of applied linguistics such as discourse analysis, critical discourse analysis, stylistics, phonetics, phonology, graphology, sociology and sociolinguistics. Sociolinguistic profiling stems from the field of sociolinguistics directly. Depending upon the concept that our linguistic performance is greatly affected by a number of social factors, namely age, educational level, gender, geographical and social class, forensic linguists can determine the author of the anonymous text, or the origin of it. Sociolinguistic profiling is needed or required when police have no strong hypotheses about the author's identity. In this case, forensic linguist searches for linguistic clues to solve the mystery of the dispute. Linguistic clues are age, gender, social and regional background of the author (Coulthard et al., 2011, p.2).

\section{Authorship Attribution:}

Forensic linguists are asked to do authorship attribution when there is a dispute on one or more texts and one or more authors. In this case, linguists search for linguistic patterns at all levels: vocabulary, syntax, grammar, semantics, punctuation and orthography. The forensic linguist is provided with text(s) of the suspect, called disputed texts, and other text(s) of known author to enable them to compare and contrast different texts. Disputed texts can be wills, threat letters, suicide notes, tweets, face book and whats app messages. It is worth-mentioning that the shorter the text, the more complicated the task. When the text is long, the discovery of distinctive features of the text or the author becomes easier. Forensic linguistic analysis makes full use of the contribution of other fields like statistics and computational linguistics. Forensic linguists make quantitative analysis of large amounts of data (ibid, p. 3).

According to Coulthard (2010), every native speaker has his/her distinct language at the spoken and written levels. This is called an idiolect. Everyone has his/her own vocabulary, lexical and grammatical preferences, 
pronunciation and accent. In this way, linguists can easily detect the linguistic fingerprint of any person (p.22).

Related to this is the forensic linguistic analysis of handwriting in manuscripts for detecting forgery. Again, everyone has his/her own specific and distinctive handwriting just like fingerprint (Ramayana, Sani and Moghadam, 2016, p.379).

Sumit Kumar and Surbhi Mathur state that identifying distinctive linguistic features which distinguish an author from the other helps a lot in determining the identity of the author of the disputed text in cases like ransom notes, threatening letters and wills (Sumit Kumar \&Surbhi Mathur, 2018, p: 2).These distinguishing stylistic features are recurrent in the texts written by the same writers in many contexts. They are sometimes called style markers. They include the way the authors space the margins, the way they form paragraphs and the length of them; some writers do not make paragraphs. The way, writers insert page number, headings and subheadings, and their absence or presence differs from one to the other. The way they emphasize some words or phrases whether using bold, italics or underlining, also differs. Everyone has his/her own idiolect: different use of vocabulary, choice of lexis and grammar, preference of certain tenses. Furthermore, some writers have misspelling of certain words fixed in their mind and are reflected in their performance. Frequency and repetitions of certain words, structures, collocations and lexical bundles are a distinguishing stylistic feature. Dealing with these features is the domain of forensic stylistics which helps identifying authorship of disputed texts. It is also called stylometry (Correa, 2013, p. 1). It is helpful in both fields of written and spoken texts. It utilizes scientific analysis in determining and measuring content and meaning. It is effective in identifying authorship and plagiarism (Ariani et al., 2014, p. 224). 
It is noteworthy that FL is very successful in the detection of plagiarism. According to Coulthard (2010), it is known as a 'patchwork'; Johnson calls it collusion (p.26).He defines it as a theft, or an unacknowledged use of other's texts: or someone who tries to pass off some else's work as his/her own (2005, p.23).He argues that the idea of plagiarism is related also to the notion of idiolect; everyone has his/her own use of language. Linguists can easily discover if two texts share a sequence of ten or more identical words. They can find out if two authors copy each other or copy someone else. In addition, there are soft wares that are very helpful and effective not only in cases of academic plagiarism, but in miscarriage crimes and other cases, as well. Coulthard adds that checking plagiarism in the same language becomes very easy, particularly with the existence of new soft wares, but if the text is translated from one language into another, it becomes difficult, since the direct comparison with the original text cannot be made. Plagiarism can be found in dictionaries.

\section{Interactional Meaning:}

Forensic linguists can identify an anonymous speaker in a phone conversation, especially those who threat, extort, conspire and blackmail. The prominent one in this field is Professor Roger Shuy who has analyzed covert tapes used by the police to prosecute what he calls 'language crimes' (Grant, 2012,p. 179).Language crimes are those ones that are linguistic in their nature, or rather performed mainly by language like threatening, bribing, extorting and conspiring. Language crimes are discussed later in this paper.

Speaker identification is the most frequent practiced form in FL. Daniel Jones is one of the pioneers of phonetics science. One of his early approaches was the use of spectrograph which came to be known later as the voice print technique which was actually used during the Second World War. It included a comparison of spectrograms of linguistically identical 
utterances of different speakers to determine whether they belong to the same speaker or not (Sinha, 2015, p. 155).

Forensic phonetics is the science that deals with cases of speaker identification, especially when there is a dispute over the speaker. So, it makes a comparison of recordings of a disputed/suspect voice with one or more unknown recordings. Phoneticians utilize a combination of auditory and acoustic tools and methods. It is worth-mentioning that they analyze the speech of their native language.

\section{Determining Meaning:}

Forensic linguist provides interpretation of legal texts. S/he can provide meaning of slang or ambiguous words. S/he is asked to introduce evidence in the cases of disputed meaning like meaning in contracts to determine whether particular phrases constitute a threat or a defamation.

Forensic linguistic evidence is needed in cybercrime i.e. those that refer to crimes committed on line, using common technologies as computers, internet and smart phones. These crimes also include hatred crimes, libel and fraud. They may be traditional crimes like theft but using internet.

\section{Trade Mark Disputes and Copyright Infringement:}

Forensic linguists can provide help not only in criminal investigations but in civil cases, as well. They can work as experts in trade mark disputes and copyright problems, most successfully, plagiarism detection.

Shuy (2002, pp.95-109) explains his contribution to the case of McDonald's Corporation against Quality Inns International. McDonald's claimed that they own not only the name but the prefix Mc as well. The corporation sued any other company or corporation for using this prefix in any trademark: in hotels Mc Sleep, Mc Fries, Mc Fish, and Mc Shakes. Mc means son of. Shuy made a corpus linguistic analysis and found that the prefix was generally used since long time, and gave examples like Mc Art and Mc Cinema. But the judge ruled in favor of Mc Donald's. So, they were given the full control over the use of the prefix Mc (Coulthard, 2010, p.21). 


\section{Forensic Phonetics:}

It is used to identify speaker through his/her accent, pronunciation, regional background. It helps in determining similarities and differences among speakers through analyzing recorded tapes. It is worth-mentioning that there are intra-author and inter-author variations.Intra-author means the ways in which the author's text differs from other author's texts, while interauthor refers to the ways the different texts of different authors differ from each other.

\section{Language Crimes:}

Simply, criminology is the science that studies crime: its creation, development, and prevention. Crime is examined through law and other sciences like psychology, sociology, biology and medicine. It is an applied science.it is not a closed science (Momeni, 2011, p.733). It needs experts from different fields. Crimes are committed in different forms and different ways. Nowadays, some forms of crimes are committed in internet. This necessitates the help of internet experts. Actually, it is difficult to have a comprehensive and acceptable definition of criminology.

Longman dictionary defines crime as 'illegal activities in general'. Language crimes are linguistic crimes by nature. Gibbons (2003, p.261) states that there are a number of speech acts that are illegal. In other words, there are some crimes that are committed by performing some kinds of illocutionary acts like perjury, offering bribe, threatening, soliciting an illegal act, namely hiring a hit man and libel. Language crimes also include defamation, conspiracy and plagiarism (Shuy, 1993, p.98). Criminology deals with language crimes, but forensic linguists provide a great assistance in these types of crimes.

According to Shuy, language crimes differ from other crimes in that these crimes, the doer (criminal) does not need to do physical harm to the victim, unlike other crimes such as murder, rape, beating and theft. Crimes perpetuated by means of language are all about illegal speech act (Tiersma 
and Solan, 2012, p.1). In other words, these crimes are, in essence, speech acts. Speech act theory was introduced by John Austin in 1962 and developed by John Searle (1969) and other linguists. They are of opinion that utterances can perform actions and convey information at the same time. Any speech act has three components: locutionary act which is the act of saying; illocutionary act that is what is meant or the speaker's intention, and perlocutionary act, that is the effect it has on the listener. A threat, a promise or a warning may have the same effect on the listener, namely getting him/her to do something. But threat differs from the other acts in that there is an accompanied timidation with it (Correa, 2013, p. 2).It is worthmentioning that speech act theory application is relevant not just to the criminal law, but also to the civil law like contacts, for example.

Some speech acts are characterized by the intent of the speaker, referred to as speaker's illocutionary force, others by the effect the act has on the hearer, known as the act's perlocutionary effect. All language crimes concern themselves with the speaker's intention. One has to be intended to solicit a crime in order to be guilty of solicitation. Other crimes focus on the perlocutionary effect of the speech act. For example, if the speech act does not have the effect of intimidation, it is not an act of threatening even if the speaker has the intention of threatening (Tiersma and Solan, 2012, p. 2).

According to Austin, some verbs are performatives; namely to say is to perform an action. For example, if the speaker says I promise, she /he performs an act of promising. Other acts cannot be performed by saying the utterance directly, for example, an act of lying cannot be performed by saying I'm lying. This means that not all acts can be performed by direct speech act but sometimes indirectly (ibid, p. 3).

Intentions in speech acts are very important along with the propositional content. Intentions are also important in FL.They enable forensic linguists to identify the goals and beliefs of the speaker (Khoyi and Behnam, 2014, p.315).They add that speech acts and conversational maxims are effective for criminal conviction or acquittal. 
Concerning legal discourse, Danet classifies speech acts, based on Searle's classification, as follows: firstly, representatives: types of verbs that commit the speaker to assert the truth of proposition; they include testifying, swearing, asserting, and claiming. Secondly, commissives: types of verbs which commit the speaker to do something in the future such as contracts, marriage ceremonies and wills. Thirdly, expressives: types of verbs that express the speaker's psychological state and attitude like apologizing, warning and excusing. Fourthly, declaratives: types of verbs that express a sort of correspondence between their propositional content and reality, such as nominating definitions of concepts, and lawyers' objections to confessions. Fifthly, directives: types of verbs that express future-oriented speech acts like getting someone to do something such as soliciting, persuading, inciting etc. (Khoyi et al., 2014, p.316).

Shuy presents a table that explains the main differences and similarities among different language crimes.

\begin{tabular}{|l|l|l|l|l|}
\hline & Threatening & Warning & Advising & Promising \\
\hline To the speaker's benefit & $\mathrm{X}$ & & & \\
\hline To the hearer's benefit & & $\mathrm{X}$ & $\mathrm{x}$ & $\mathrm{X}$ \\
\hline To the hearer's detriment & $\mathrm{X}$ & & & \\
\hline $\begin{array}{l}\text { From the speaker's } \\
\text { perspective }\end{array}$ & $\mathrm{X}$ & $\mathrm{X}$ & & $\mathrm{X}$ \\
\hline $\begin{array}{l}\text { From the hearer's } \\
\text { perspective }\end{array}$ & & & $\mathrm{X}$ & \\
\hline Speaker controls outcome & $\mathrm{X}$ & & & \\
\hline Hearer controls outcome & $\mathrm{X}$ & & $\mathrm{x}$ & \\
\hline
\end{tabular}

(Shuy, 1993, p.98).

Shuy develops a new concept that he calls conversational contamination. He emphasizes its importance in stating whether the person committed the language crime or not. For example, for a conspiracy or a solicitation crime to take place, it is important to know who introduces the topic, and how the other person responded or 
reacted. This only happens in the conversation. Moreover, agreeing with a detailed plan differs from being silent or answering with 'uh-huh' (Correa, 2013, p. 3).Shuy adds that 'uh-huh' does not mean an agreement in all cases. It can be regarded as a marker to signal that the other person is listening or understanding or being on the track. Dealing with language crimes, from Shuy's point of view, necessitates that the linguist has to be well-trained in pragmatics to identify easily whether a crime or speech act was committed or not.

In this respect, some language crimes will be presented like solicitation, conspiracy, bribery, threatening and perjury. After presenting language crimes, an application to certain cases in Egypt will be done to prove how Forensic linguistics is effective and helpful in dealing with language crimes in particular.

\section{Solicitation Crime:}

It involves asking or inducing someone else to commit a crime. Different terminologies can be used to refer to the same concept incitement, abetting and instigation ( Khalifa, 2018, p.157).All the terms mean to induce someone to commit the crime by influencing one's will either by creating the idea of the offence in his/her mind or by encouraging the person to take the decision to commit the crime. Different speech acts in this crime can be used such as tempting, persuading, seducing and sometimes threatening. Tiersma and Solan state that this crime does not have to be performed, and the court needs just to prove that the solicitor intended the crime to be committed (p.3).This means that the essence of solicitation or instigation is language. Moreover, the most frequent forms of solicitation refer only to the illocutionary force of the act, instigates or solicit, means trying to persuade others to do something. They add that the solicitor must be sincere. Linguists opine that sincerity is not a requirement to perform all speech acts (Searle).A speaker can perform an act of promising even if (s) he does not have the intention to keep it.But in solicitation crime, one must have to intend the 
crime to be committed either by direct or indirect speech act. When the solicited person agrees to commit a crime, this leads to another crime, namely conspiracy.

\section{Conspiracy:}

It involves two or more persons who agree to commit a crime. Article 40 of the Egyptian Penal Code does not determine a precise form that the agreement has to take. It could be written or oral. It can be done in one or more meeting (Khalifa, 2018, p.159).Agreement can be proven circumstantial evidence. In addition, some jurisdictions condition that the agreement has to be followed by a deliberate overt physical act intended to further the conspiracy. There are linguistic clues from which a jury can infer that if there was an agreement or not. For example, using the plural pronoun 'we' can help in establishing the presence of conspiracy (Tiersma and Solan, 2012, p.8).

\section{Bribery:}

This crime involves giving an official person money or an item of value with the intent of inducing him/her to act in a particular way in his/her official or professional capacity (ibid, p. 9).So, accepting or receiving money or any item of value is condemned as a bribery crime especially when the person who accepts or receives is a governmental official or a witness in court in a case. Also, the money or item offered must be with the purpose of influencing official action. According to Momeni, FL examines crimes such as bribery with a new look (2011, p.734).She opines that language crimes are sub-part of criminology and linguistics. Forensic linguists have the task to answer questions like: does the culprit offer the bribery? Does (s) he accept the bribery? This can be done analyzing the conversation between the doers with focus on the speech acts performed. Shuy states (1993, pp. 53-56) that there are three conditions for bribery speech act: bribe offer is a performative speech act; it can be an indirect offer; bribe offer might not have an illegal vocabularies like ' if you do me a favor, I will compensate you', or just 
saying ' I will compensate for you'. The proposal can be embedded or rather lacks the explicitness.

Shuy is of opinion that bribery is one of the most common 'white-collar crimes $(1993, \mathrm{p} .20)$. The term refers to crimes which are committed by persons in institutional positions to get an illegitimate financial gains.

\section{Threatening:}

Threats are not always criminal acts. Some of them can be criminal. Threats are involved in crimes of extortion and blackmailing particularly when the victim agrees to give money or property to the one who threatens to do something bad to the victim (Tiersma and Solan, 2012, p. 10). As speech acts, threats are similar to warnings and predictions in that all of them talk of events that may happen in the future. But threats differ from other speech acts in that the threatner expresses his intention to bring about the cause of the event, for example: I will kill you if you do not give me the money. The speaker may state or imply the cause of the harm that will happen in the future.

Another requirement for threatening act is that the speaker must believe that the future event will be bad for the threatened. Warnings also refer to bad events to happen in the future, but warning is to protect the listener from harms that may happen to him/her in the future. Contrary to threats, promises express an intention which is beneficial to the listener (ibid, p.11).A third requirement for threats is that the speaker must intend to intimidate the listener by his utterance. A final requirement that is common to many speech acts is that the threatner must appear to be sincere. This means that the speaker does not have to be actually sincere, but pretends to be sincere.

Threats, like many other speech acts, can be indirectly or nonverbally such as hand gestures or pointing by the gun or even making the shape of gun by hands to a witness entering the court. Threats can be performed also by indirect speech acts like what should I do to retaliate? (ibid, p.13). 


\section{Perjury:}

It normally involves lying under the oath. People commit perjury by means of language. Those people who perform perjury crime depend upon a presupposition of a speech community that shares a set of conventions and knowledge regarding meanings of the words, and the way these words combine to construct sentences and larger units of discourse (ibid,p.19). U S Federal Law defines a person who commits perjury crime as a person who 'willfully and contrary to such oath states or subscribes any material matter which he does not believe to be true' (ibid, p.14).

Five language crimes have a great deal in common. They can be performed either directly or indirectly, except perjury which is performed directly. All of them require some kind of intent, and most importantly, they are committed through speech acts. They differ in the elements of each crime and the extent to which the speech acts must affect the listener, and whether the speaker must actually be sincere or appear to be sincere.

\section{Application:}

In 2008, there was a very famous case in Egyptian society. The members involved in this case were well-known: Egyptian business man Hesham Talaat Mustafa, Suzan Abdal Satar Tammem, a Lebanese singer, and Mohsen AlSokary, a former security officer. Suzan was Mustafa's beloved; he supported and protected her. She had problems with her exhusband, Adel Matook. He provided her accommodation and gave her lots of money. He divorced her from her husband with whom she had a lot of troubles and problems. After two years, Suzan left Mustafa and eloped with her lover, Riyad AlAzway, an Iraqi businessman. Mustafa decided to take revenge on her, as she betrayed him and she took his money also. So, he solicited and conspired with Alsokary to kill her. He threatened her of killing and or causing her a permanent disability. She reported him to police in Dubai and in London. He was watching and pursuing her. In this case, there are many language crimes like threatening, soliticition and conspiracy. All of 
them depend mainly on speech acts. Prosecution and court convicted Mustafa of Solicitation, conspiracy and helping in killing the Lebanese singer. He was convicted fifteen years in prison. Alsokary was convicted by the prosecution and court to life imprisonment (incarceration) for killing the artist. The researcher has chosen this case in particular, as it contains more than one language crime. Moreover, the court, in her sentence, depended upon the recorded conversation between Mustafa and Alsokary which reveals the intentions of both criminals. Speech acts, especially threatening, soliciting, persuading and conspiring, play a very important role in this case, in general, and conviction, in particular.

\section{Solicitation/ incitement/ instigation:}

\section{Speech Acts and Intention:}

The intention of the solicitor was clear and strong; for about two years, he insists on killing her: he sent his men watching her; her moves were followed. Solicitation crime involves inducing or persuading someone else to commit a crime: Mustafa persuaded Alsokary to kill Suzan as she betrayed him and took his money. Inciting him, he gave him much money. He provided him with visas, accommodation, addresses, phone numbers and flat contract. He influenced AlSokary's will to kill her though the later did not know her well. Mustafa's illocutionary force was to get rid of her 'I want to get rid of her', 'throw her from the balcony in a way like committing suicide like Soad Hosni', 'hit her by car' or ' any car accident'. He gave him her locations 'she is now in Dubai', 'she is now in London'.Alsokary suggested different ways to get rid of her: 'report her to the police or Interpol, she had many legal problems', 'we make a permanent disability to her', 'put drugs in her flat and report her to the police'. All of his suggestions were refused by Mustafa. Finally, Alsokary agreed and murdered her. So, this means that Mustafa was sincere, and he intended fully to get rid of her. He encouraged Alsokary to take a decision, to put a plan and execute it fully. 


\section{Threatening:}

The most important element in threatening is the effect upon the threatened person, the perlocutionary act, namely intimidation, the threatner must intend to intimidate the person. He has to express his intention, and his intention must cause harm to the threatened person or rather the victim. Mustafa did this by threatening her and her brother either by sms or by telephone calls.

The perlocutionary effect upon her was intimidating, as she changed her phone numbers and addresses many times. Once she knew that he knew her address, she escaped to somewhere else. She asked for protection from the police in Dubai and London. Due to the effect of intimidation upon her, she went to the police station many times and got a restraining order against Mustafa. She showed the police some Sms on her mobile phone. All of the sms and the mobile calls were threatening messages to her and her brother. He threatened her of killing, making a permanent disability, report her and her bother to the Interpol. In addition, he threatened her of kidnapping, Alsokary said:' he asked me to kidnap her and bring her to Egypt in his private plane'. She asked for protection and restrained order.

He was sincere in his threatening: he gave money, large sums: two million dollars, visas, her car number, her addresses and her flat contract to facilitate AlSokary's mission of killing her. He repeated many times 'I want to get rid of her'. Moreover, he suggested different ways of killing her "throw her from the balcony to seem like suicide accident in the same way Soad Hosni did' or ' hit her by a car or any car accident'. He argued with Alsokary and persuaded him to kill her though the latter did not know her. Mustafa refused suggesting making a permanent disability to her or drugs case or report her to the police and Interpol. He refuses all of Alsokary's suggestions insisting on her murder. Moreover, he asked other people to follow her and watch her. Alsokary recorded five different phone conversations in which Mustafa was soliciting him to kill her. 


\section{Conspiracy:}

It involves the agreement between two or more persons to commit a crime. In this case, both of Mustafa and Alsokary agreed together to kill Suzan despite the latter's claim that he did not agree. He said to the prosecution' I was deceiving Mustafa to get more money from him'. He made physical movements and actions which emphasizes his agreement to commit the crime. He travelled and watched her twice, and for a long time, once in London, and another time in Dubai. When Mustafa asked him one time 'why didn't you execute the mission?', he answered' there was not a good chance and do not forget that she is an artist and there are a lot of people around her'. Again, when Mustafa told him' she is in Dubai now and it is difficult to execute, he replied instantly' shame upon you, I'm a former security officer'.'Alsokary went to her flat and murdered her. He made a complete plan to kill her and executed it to the end. He bought new clothes, a knife and a portrait. He called her and told her that he is an agent from the company which sold her the flat. The company sent her a letter of thanks and a present. He asked her for a meeting. She was deceived and agreed to meet him. Entering her flat, he hit her on her head and stabbed her with the knife eight times. After killing her, he called Mustafa and told him that 'everything is ok, I had finished the mission'. Mustafa replied 'come and take the money, I'm waiting for you at Sharm AL sheik'. Mustafa gave him, in return, two million dollars. In addition, he deposited large sums of money at AlSokary's balance more than one time. He bought him the visas. He provided accommodations at the hotels. He gave him her different addresses, her car number and her flat contract to convince her that he came from the company that sold her the flat. The conspiracy crime is complete here in this case. Both of them conspired together to kill the artist. It is Mustafa who began the topic and asked Alsokary to kill Suzan. He considered the issue of her killing as ' a matter of life and death'.Alsokary agreed saying 'this is my job, I'm a former security officer'. Agreement is followed by a deliberate overt physical act intended to further the conspiracy. There was a sort of agreement and insistence on both partners. This means that there are three language crimes 
in this case, namely, threatening, conspiracy and solicitation. The court convicted both of them for these crimes, in addition to the murder crime.

\section{Findings and Conclusion:}

Language is a very important means of communication. Both of them are indispensable to human evolution. Due to the widespread of technologies, crime rate is raised. So, it is urgent to think of novel ways to identify criminals and suspects. Forensic linguistics offers a wide range of techniques of analysis of plagiarism, disputed speaker's voice, asylum analysis, especially when there is doubt surrounding an asylum applicant's claimed origin, and authorship identification.

Forensic linguists are asked to cooperate with legal authorities in many cases such as identification of the writer of threatening letters, letters containing explosives and deadly materials, writing related to the time of death and suicide telephone messages.

Law is inconceivable without language: without language, there would be no law, no trail, and in some cases, no evidence.

Although the field of FL is in its infancy, its contributions to criminal justice system are significant (Correa, 2013, p.9).

Forensic linguists aim to assist the jury in understanding the evidence by shedding lights on issues that might not be obvious otherwise.

According to Coulthard, FL works on three distinct domains of investigations:

1) The language of written legal texts.

2) The spoken language of the legal process; linguists examine police suspect interviews.

3) Forensic linguists work as expert witness: express opinions about trademarks, authorship of documents, meaning of words and expressions, and the origin of asylum seekers (Coulthard and 
Johnson, 2007).In addition, in jury trials, judges, sometimes, call experienced forensic linguists, like Peter Tiersma, and law professors to join their committee. Shuy reports his contribution to the case of McDonald's Corporation V Quality Inns International. This proves forensic linguists' contribution to the disputed trademarks.

FL is equivalent to court linguistics, judicial linguistics or legal linguistics.

Olsson is of the opinion that lawyers and forensic linguists should cooperate with each other in the interests of justice. He adds that it is the task of linguists to widen their understanding of international laws, issues of international human rights, and the relationship between law and language across the globe (Olsson, 2014, p.1).

FL has a promising future, the researcher hopes to be applied in Egyptian courts and legal system, as it provides an objective and impartial linguistic evidence. 
Ariani, M.G.,Sajedi, F.\& Sajedi, M. (2014) Forensic Linguistics: A brief Overview of the Key Elements. Procedia-Social and Behavioral Sciences, 154,222225 .

Blackwell, S. (2012). History of Forensic Linguistics. The Encyclopedia of Applied Linguistics.

Choudhary, Sumit and Mathur, Surbhi (2018). Significance of Forensic Stylistics in Fixing Authorship of Handwriting. Journal of Forensic Sciences and Criminal Investigation. Juniper Publishers.vol. 7. India.

Correa, Maite (2013). Forensic Linguistics: An Overview of the Intersection and Interaction of Language and Law. Kaboytyra/ Linguistics Kalbu Studijos. 2013.23.NR. Studies about languages.

http:// dx-doi-org/10.5755/joi.sal.o.23.5020

Coulthard, Malcolm. (2005). Some Forensic Applications of Descriptive Linguistics. Verdas-Rev.Est.Ling.Juizde for a, V9. N.1 en.2p-9-28, jan/dec.

Coulthard, M. and Johnson, A (2007).An Introduction to Forensic Linguistics: Language in Evidence.Routledge.

Coulthard, Malcolm. (2010). Forensic Linguistics: the application of Language Description in Legal Contexts. Editions de la Maison des sciences de l'homme.

http:// www.cairn.info/revue-language et-societe-2010.2-pages-15.htm

Coulthard, Malcolm and Sousa, Rui, Silva. (2011). Forensic Linguistics. Universide de Federal de Santa Catarina

Coulthard M, Grant T, and Kredens (2010). Encyclopedia of Forensic Sciences :Law Forensic Linguistics.In:Johnstone B,Wodak R, and Kerswill P (eds) The SAGE Handbook.

Derin, Tatum, Evizareza, Susy, Deliani and Budianto Humuddin . Exploring the Past, Present, and Future of Forensic Linguistics Study: A Brief Overview. Universitas Lancangkuning, Pekanbaru. Indoensia.

Durant, Alan. (2002). Applying Linguistics:Questions of Language and Law. In, Sadakazu Fujii et al (eds.) Praxis of Language, 6 volumes. University of Tokoyo Press.Vol 5: 'Politics, edited by Hidetaka Ishida and Yoichi Komori, pp.253-81. 
Jihan Hassan Mohammed Ali. (BIJHS) 2020, 2 (1):39 - 65

Forensic Language Analysis. Number 509 September 2015 Post Note. The Parliamentary Office of Science and Technology, Westminster, London SwIAoAA Gibbons, J. (1994). Language and the Law, Harlow: Longman.

--- (2003). Forensic Linguistics: An Introduction to Language in the Justice Systems, Blackwell: USA.

Grant ,T., \& Perkins, R.(2012). Encyclopedia of Forensic Sciences, Second Edition: Forensic Linguistics. Birmingham, UK: Aston University Centre for Forensic Linguistics.pp 174-177.

Houtman and Suryati. (2018). The History of Forensic Linguistics as an Assisting Tool in the Analysis of Legal Terms. Faculty of Teacher Training and Education, PGRI University of Palembang.Indonesia.

Doi:10.28946/s/rev. Vo12.Iss2.135.pp215-233.

http://journal.fh.unsri.ac.id/index.php/sriwijayalawreview

Khoyi, Amin Mohammad Zadegan and Behnam, Biook. (2014). Discourse of Law: Analysis of Cooperative Principles and Speech Acts in Iranian Law Courts. Asian Journal of Education and e-Learning.Vol.02

www.ajouronline.com

li, Xuehua. (2011). The Study on Forensic Linguistic Analysis of Applied Linguistics Based on Data Analysis. S.Lin and X.Haung (Eds): CSEE. PartV. CCIS218, pp528-532. Springer-Verlag Berlin Heidel-berg.

Momeni, Negar (2011). Forensic Linguistics: A Conceptual Frame of Bribery with Linguistic and Legal Features (a Case Study in Iran). International Journal of Criminology and Sociological Theory, Vol.4, No.2, December 2011. 713-744.

Olsson, J. (2008). Forensic Linguistics, Continuum International Publishing Group, London.

--- (2014). What is Forensic Linguistics? The text. Co

Uk/ docs/what_is . Doc> Acessoem, 25.

Olsson, J., Lunchjenbroer, J.(2013). Forensic Linguistics. A\&C Black.

Ramezani, Farshad, Arefeh Khosousi Sani and Kathyoun Moghadam (2016). Forensic Linguistics in the Light of Crime Investigation. Social Science and Humanities. Pertanika J.Sci-sci \& Hum.24 (1) 375-484

http:// www.pertanika.upm.edu.my/ 
Shuy, Roger. (1993). Language Crimes: the Use and Abuse of Language Evidence in the courtroom. Cambridge, MA: Blackwell.

(1997).The Language of Confession, Interrogation, and Deception (vol.2).Sage publication.

Shuy, Roger. (2002). Applied Linguistics in the Legal Arena. Incadlin, Chris and Srikant Saraangi (eds.) Handbook of Applied Linguistics Berlin: Mouton de Gruyter.

---

(2005). Creating Language Crimes: How Law Enforcement Uses (and Misuses) Language. New York: Oxford U Press.

Sinha, Sweeta. (2015). Forensic Linguistics and Forensic Phonetics: An Introduction. International Journal of Interdisciplinary and Multidisciplinary Studies. Jawaharlal Nehru University, UP, India. Vol.2, No.6, 153-157.

http:// www. ijims.com.

Solan, Lawrence and Peter Tiersma (2005). Speaking of Crime. Chicago: U Chicago Press.

(2012). The Language of the Crime. Solan, Lawrence and Peter Tiersma

http://ssrn.com/abstract=2017652.Brooklyn Law School Legal Studies. March 2012. Research Paper .No.263. 